\title{
LEFT BEHIND: AN OVERVIEW AND CRITIQUE*
}

\author{
Robert J. Phillips ${ }^{\dagger}$
}

Abstract: The LEFT BEHIND series of novels, published in the United States in the 1990's through 2007, popularized a "Premillennial Dispensational" view of eschatology among millions of Protestants. Tapping on the quiet but substantial market uncovered by publication of bestselling THE LATE GREAT PLANET EARTH in 1970, the series has become for many Americans the default setting for understanding the apocalyptic literature and teaching of scripture. Various theological traditions offer serious critique of the assumptions and conclusions of this approach in general and specifics of the book series in particular. Yet the series has offered incentive for many across the theological spectrum to kindle renewed interest in salient teachings of Christ and scripture regarding the nature and relevance of eschatology for contemporary Christianity. Contributions and shortcomings of these popularized works are assessed against the historical and theological origins and evolution of this teaching. The LEFT BEHIND series, as a work of Christian fiction, can offer excitement to the readers but does not have sufficient theological grounding to offer decisive guidance on how the Kingdom of God will enter into its fullness among humankind.

\section{INTRODUCTION}

The Left Behind series, consisting of sixteen novels published between 1995 and 2007, captured the imagination of millions of Americans and other Protestants around the world. Over fifty million copies of the books were sold worldwide as of 2004, with the current estimates of total sales exceeding 65 million copies. Authored by California pastor, Bob Jones University graduate and conservative activist Tim Lahaye, with writing assistance from Jerry Jenkins, the series financially invigorated Tyndale Press, the Christian publishers of the novels, and has stoked

\footnotetext{
* (C) 2020 Robert Phillips

${ }^{\dagger}$ MLitt 2014 University of St Andrews
} 
a continuing discussion of the significance and impact of the novels on everything from American politics to modern Protestant evangelical definitions. ${ }^{1}$

Although the initial book, Left Behind, and the subsequent volumes draw from a variety of biblical texts, this research focuses on an examination and critique of the series's understanding and use of the book of Revelation in establishing the narrative plot and the theological world view it upholds. The premillennial dispensational frame of reference (explained on page 286 below) that defines the plot and infuses the spiritual content of the series will be explored. The study will conclude with critical observations on the relationship of the series to the evangelical subculture in the contemporary West.

\section{Theological And Historical Antecedents}

The series was not produced in either a literary or a theological vacuum. The number one non-fiction bestseller in the United States in the decade of the 1970's was Hal Lindsey's, The Late Great Planet Earth, with nine million copies sold during the decade and 28 million copies in print by 1990 alone. Lindsey's breezy conversational tone and confident linkage of 1970's events to biblical predictive prophecy through a premillennial dispensational lens won a wide popular hearing and spawned a number of follow-up books, such as his 1972 work, Satan is Alive and Well on Planet Earth. ${ }^{2}$

Earlier than either Lindsey or Lahaye was the movie, A Thief in the Night, filmed in the 1960 's by a fledging Christian movie company for $\$ 60,000$ and seen by roughly 300 million people since its premier. Lahaye specifically credited this movie, which for years was a staple offering in numerous conservative Protestant churches, as providing partial inspiration for his series. The film offers a fictionalized scenario of the terror felt in the aftermath of the Rapture, a crucial piece in premillennial dispensational thought. The Rapture is the sudden disappearance of true Christians into God's presence, while the satanic forces of the antichrist make life unpleasant for those left behind. The stated intent of the movie was to shock the audience, particularly high school youth groups, into concern over the consequences of not becoming a true Christian. The title, drawn from 1 Thess 5:2, is slightly misplaced, given that the text refers to the day of the Lord's return as

\footnotetext{
${ }^{1}$ Amy Johnson Frykholm, Rapture Culture: "Left Behind" in Evangelical America (New York: Oxford University Press, 2004), 1-2.

2 Paul Boyer, When Time Shall Be No More: Prophecy Belief in Modern American Culture (Cambridge: Harvard University Press, 1992), 5.
} 
coming like a thief in the night, whereas the plot of the movie focuses on the thief-in-the-night suddenness of the removal of true believers. ${ }^{3}$

The frame of reference for the series is a premillennial dispensational approach, a method of biblical interpretation with historical origins in the work of John Nelson Darby, a Plymouth Brethren pastor in the middle $19^{\text {th }}$ century who began his spiritual journey as an ordained clergyman in the Church of Ireland. Darby's interest in developing a coherent system of biblical interpretation, mixed with his disenchantment with much of the Protestant religious organizations of his day, set the stage for his teaching that God's dealing with humanity is divided clearly into a series of epochs or "dispensations." The "Church Age" is the current dispensation and, consistent with Darby's conviction of the apostasy of the existing church, the age will end with divine judgement. Getting people saved, thus avoiding everlasting ruin, is the preeminent purpose of the church. All other church involvement in the world is a distraction, since humanity will continue its downhill moral descent until destruction. Darby's emphasis on eschatology, in particular his orderly approach to ticking off events and signs presaging the end of the world and the return of Christ, gained intense interest on both sides of the Atlantic. ${ }^{4}$

Darby's work received wide circulation through the study notes of the immensely influential Scofield Reference Bible, produced by C.I. Scofield in the late $19^{\text {th }}$ century and widely used as a primary study Bible by many Protestants for nearly a century. Scofield confidently interpreted numerous eschatological passages through the lens of the premillennial dispensational perspective, providing readers through his study notes with direction on how to interpret the texts. Some have seen irony in Scofield's emphatic insistence that one can come to all crucial right answers by reading the Bible independent of institutional interference even as he provided the readers copious notes on how to read the Bible correctly. ${ }^{5}$

One transatlantic shift in emphasis that disturbed Darby was the American refusal to embrace his notion of the apostate nature of existing organized Christian churches. This dualism of the pure church in its spiritual, heavenly state in contrast to the corruption of the existing earthly Christendom informed Darby's understanding of everything from who qualified for the Rapture

\footnotetext{
${ }^{3}$ Dean Anderson, “The Original 'Left Behind,"” Christianity Today, March 7, 2012.

${ }^{4}$ Paul Boyer, When Time Shall Be No More, 87-88

5 S.R. Spencer, "C.I. Schofield," in Dictionary of Major Biblical Interpreters, ed. Donald McKim (Downers Grove: Intervarsity Press, 2007), 908-910.
} 
to Israel's blessing in the millennium but not into eternity. This approach largely was displaced by American proponents who argued for the need to reform rather than reject existing churches. ${ }^{6}$

While a review of the entire premillennial dispensationalist approach is beyond the scope of this study, the role of the book of Revelation in the Left Behind template of eschatological events is crucial. Highlights in the series lifted from texts in Revelation include the rule of the Beast on earth tormenting those left behind following the Rapture (Rev 13:11-15), who requires the "mark of the Beast" identification on survivors to engage in financial and social transactions (Rev 13:1618). The collision of the armies of the Beast-Antichrist and God at the battle of Armageddon (Rev 16:16) and the central role of the millennial reign of Christ preceding the final cataclysmic destruction of Satan (Rev 20:4-6) and the permanent establishment of the Kingdom of God on a new earth and new heaven (Rev 21:1-4) round out major highlights.

The precise nature of prediction in the Left Behind series and the confidence with which Bible verses are aligned to buttress the road map-approach to the Kingdom offer tremendous appeal, as certainty pushes nuance and ambiguity out of the picture. Amy Frykholm documents the dynamic of this substantial appeal for many who read and embrace the world view reflected in the series. $^{7}$

Difficulties abound with the premillennial dispensational approach to Revelation. The first issue is in the perspective itself, the hermeneutical engagement with the text. Richard Bauckham has observed that "Revelation does not predict a sequence of events, as though it were history written in advance." Such an approach reflects a profound misunderstanding of the nature of apocalyptic literature in general and the Christian prophetic element of Revelation in particular. Conflict will precede the fullness of the Kingdom and the reign of Christ, but not in categories amenable to a digital calendar or watch. ${ }^{8}$

The Darby-Scofield template that overlaps the plot of the Left Behind series is, in historical terms, a recent and minor player within the expanse of Christian interpretive tradition. Robert Clouse, in editing the insightful and balanced work, The Meaning of the Millennium: Four Views,

\footnotetext{
${ }^{6}$ Stephen R. Spencer, "Dispensationalism," in The Encyclopedia of Christianity, Vol. 1, ed. Jaroslav Pelikan et. al. (Grand Rapids: Wm. B. Eerdmans, 1999), 855.

${ }^{7}$ Amy Frykholm, Rapture Culture, 86-88.

${ }^{8}$ Richard Bauckham, The Theology of the Book of Revelation (Cambridge: Cambridge University Press, 1993), 149150.
} 
makes clear that while a general premillennial understanding of last events has precedent reaching back to the early church, the dispensational approach is a very new player on the stage. The amillennial approach of St. Augustine held sway within the church for centuries, arguing the solitary reference to the millennium in Revelation was symbolic rather than literal. This was followed by an emerging postmillennial understanding in which the church continues to impact the world for good until the moment of Christ's return, a popular notion for many Christians in the previous centuries. The idea of a literal thousand year earthly reign by Jesus, preceded by the removal of true believers through the Rapture (a word not found in any biblical text with that meaning), is very new in pedigree. ${ }^{9}$

Several major Christian traditions clearly repudiate the premillennial dispensational approach. Representing a classic Reformed tradition understanding of eschatology, J. Gresham Machen, in line with mentor B.B. Warfield of Princeton Theological Seminary, explicitly rejected this understanding as incompatible with scripture in general and Reformed theology in particular. Although his defense of the inspiration of scripture became a bedrock resource for modern American fundamentalism, Machen's rejection of dispensationalist theology kept him distant from having the fundamentalist tag pinned on his lapel. ${ }^{10}$

The Wesleyan-Arminian tradition on both sides of the Atlantic likewise has offered neither endorsement nor embrace of the theological underpinnings of this approach. While that tradition fully aligns with the affirmation of the return of Christ and the ultimate victory of the Kingdom, Wesley's classic sermon on the subject offers no specifics friendly to a Left Behind approach, while the holiness tradition with Methodism strongly trended toward a postmillennial understanding in the $19^{\text {th }}$ century and reflected more suspicion than embrace of dispensationalist views. $^{11}$

\section{IMAGERY FROM THE BOOK OF REVELATION}

Against this background a critique of certain specific uses of Revelation in the Left Behind series comes into view. The idea of the Rapture, the catastrophic event that jump-starts the series,

\footnotetext{
${ }^{9}$ Robert Clouse, The Meaning of the Millennium: Four Views (Downers Grove: Intervarsity Press, 1977), 9-12.

${ }^{10}$ D.G. Hart, Defending the Faith: J. Gresham Machen and the Crisis of Conservative Protestantism in Modern America (Phillipsburg: New Jersey, P\&R Publishers, 1994), 64-65.

11 Vic Reasoner, "The Hope of a Christian World: Wesleyan Eschatology and Cultural Transformation," in The Arminian Magazine, Vol. 25, Issue 1 (Spring, 2007): 3-4. See also John Wesley, “The Great Assize," Wesleyan Holiness Digital Library, accessed August 8, 2020.
} 
is not found in Revelation. The "mark of the Beast," identified as a microchip implanted in each person in the post-Rapture world to allow free access in society, is a term from Rev 13:16-18. Both Beale and Mounce see the Jewish use of phylacteries on the forehead as providing the clearest symbolic connection to the placing of the mark on the forehead. Beale likewise insists the reference is clearly intended to be symbolic rather than literal, with a variety of possible explanations relating to the use of Roman coins and official imprints. Most interpreters agree that any understanding of the mark that would be unintelligible to the first readers of Revelation would be problematic as a correct interpretation today. ${ }^{12}$

Lahaye and Jenkins identify the Beast with the character of Nicolas Carpathia, a charismatic, multi-lingual Romanian who eventually controls the United Nations and seeks to establish a world ecumenical apostate church, an interpretive approach with which Darby would have been pleased. Carpathia eventually is revealed as the Antichrist, a term not found in Revelation but mentioned five times in $1 \& 2$ John, albeit more as a descriptive category of those who are against Christ rather than as references to a particular individual. ${ }^{13}$

Armageddon, referenced in the Bible only in Revelation 16:16, is part of the bloody clash between Satan and the forces of Heaven that brings about the death of the Antichrist. The Left Behind series identifies the exact spot in the valley of Megiddo. There is a problem. Traditional interpretation of this reference in scripture do not limit the location to a literal geographic spot which one can track through using a GPS system, but rather speaks to the typology of the final conflict between Christ and Satan that encompasses the entire earth. Beale notes that other Old Testament prophecies speak of the culmination of God's judgment in Jerusalem, while the literal valley of Megiddo is a two day walk from the city. ${ }^{14}$

Revelation 20-21 forms the basis for the final Left Behind books, culminating in Kingdom Come in 2007. There, the forces of evil, under allegiance to Satan, make a last attack on Jerusalem, where Jesus is completing his millennial reign. Jesus calls fire down on his opponents, who are eliminated, while Satan joins the Beast and the False Prophet in Hell after a last scolding by Christ,

\footnotetext{
${ }^{12}$ Robert Mounce, The Book of Revelation (Grand Rapids: Wm. B. Eerdmans, 1977), 263-5. See also G.K. Beale, The Book of Revelation (Grand Rapids: Wm. B. Eerdmans, 1999), 718-728.

${ }^{13}$ Tim Lahaye and Jerry Jenkins, Left Behind (Carol Stream: Illinois, Tyndale House, 1995), 256-260. Regarding the use of 'antichrist,' see Glenn Barker, "1, 2 and 3 John," in The Expositor's Bible Commentary, Vol 12, ed. Frank Gaebelein (Grand Rapids: Zondervan, 1981), 323-326.

${ }^{14}$ G.K. Beale, The Book of Revelation, 838-839.
} 
completing the final victory of God on earth. Thereafter the wicked dead are judged in a moment of time, the protagonist Rayford experiences the resurrection body that returns him to peak condition consistent with a healthy man of age 30 , the New Jerusalem descends and all live happily and forever in praise of God. ${ }^{15}$

Both dialogue and details in this confrontation flow from poetic license not found in the actual text of Revelation. If one accepts a literal premillennial dispensational approach, the added details are plausible for the purposes of the novel. If the caution noted by Bauckham against reading the text in a literalistic manner is well-placed, the conflict and redemption narrative better compares with H.G. Wells' saga in War of the Worlds. If, as Anthony Hoekema suggests from an a-millennial perspective, the conclusion of Revelation points to the ultimate triumph of God rather than to an architect's drawing of events, one is free to embrace the power of the words and imagery without particularizing each event in a future historical sense. ${ }^{16}$

\section{Cultural Impact}

The impact of the Left Behind series on the evangelical subculture in the contemporary West cannot be understood apart from teasing out the cumulative impact of the premillennial dispensational hermeneutic in the $20^{\text {th }}$ century. This approach has had clear impact on the conservative wing of modern evangelicalism and its cousin to the theological right in Protestant fundamentalism in areas of science, social conscience, political and international understanding, and ecclesiology. Each will be examined in turn.

A note of caution is required. Robert Putnam and David Campbell, in their recent significant study of the impact of religion in the United States, has identified two trends that suggest the likelihood of a minimal lasting impact of Left Behind books on contemporary evangelical culture and belief. The study documents the clear decline within self-identified evangelicals of those who embrace a "literal" approach to scripture in all areas and a particular rise in suspicion among evangelicals of beliefs that tend to marry the Christian faith to one political party or point of view. As one might enjoy watching a Mickey Mouse cartoon but still set traps to

\footnotetext{
15 Tim Lahaye and Jerry Jenkins, Kingdom Come (Carol Stream: Tyndale House, 2007), 347-353.

${ }^{16}$ Anthony Hoekema, “Amillennialism," in The Meaning of the Millennium: Four Views, ed. Robert Clouse, $185-187$.
} 
kill mice in the house, so many evangelicals might read such novels for fantasy or entertainment without reordering one's values, voting patterns or church allegiances. ${ }^{17}$

Creation science, especially advocates of the young earth approach to the origin and age of the universe, has been joined at the hip with the premillennial dispensational view. As ably documented by Ronald Numbers in his definitive and balanced historical study, The Creationists, nearly every major $20^{\text {th }}$ century advocate of earth as no more than 6-12,000 years old and a universal flood covering the entire planet also align with the premillennial dispensational view. ${ }^{18}$

When Henry Morris, a leader in the young earth approach, established a creation science curriculum at Christian Heritage College in San Diego in the 1970's, Morris assured supporters concerning the faculty that, "All of these men have doctorates and are strong creationists, premillennialists, etc." Numbers noted that "most flood geologists came from churches awaiting Christ's soon return to earth," citing Morris that "If you take Genesis literally you are more inclined to take Revelation literally." It is no coincidence that the founder of Christian Heritage College and a strong proponent of young earth and anti-evolution science was Tim Lahaye. ${ }^{19}$

Anything remotely connected with a sophisticated approach to scientific inquiry or understanding of end time events is totally lacking in the Left Behind series. One can argue that the point of the books is not to establish scientific criteria for eschatological events but to produce novels that elicit sufficient attention to get one's house in order with God. Even so, evangelical scientists such as Francis Collins, pioneer in human genome research and the head of the National Institutes of Health in the United States, noticeably ignores any Left Behind scenarios in his kind but decisive critique of the creation science that the premillennial dispensational perspective affirms and supports. ${ }^{20}$

\section{SOCIAL JUSTICE ISSUES}

Insofar as social conscience related to matters of Christian engagement with poverty, injustice and oppression, the Left Behind book and series are consistent with the premillennial dispensational viewpoint that views such matters through a purely individualistic lens. The initial

\footnotetext{
${ }^{17}$ Robert Putnam and David Campbell, American Grace: How Religion Divides and Unites Us (New York: Simon \& Schuster, 2010), 110-112, 121.

${ }^{18}$ Ronald Numbers, The Creationists: The Evolution of Scientific Creationism (Berkeley: University of California Press, 1992), 284.

${ }^{19}$ Ibid., 338-9.

${ }^{20}$ Francis Collins, The Language of God: A Scientist Presents Evidence for Belief(New York: Free Press, 2006), 171179.
} 
novel opens with allusions to the pilot protagonist's mildly dirty thoughts toward one of his flight attendants, and through that volume and subsequent works in the series evil is to be fought by believing in Jesus and waiting for his return. Famines and other catastrophes are inevitable and are foretold as the various bowls of wrath spill over the unrepentant remnants of humanity (Revelation 16). Nothing resembling a Christian social conscience is in evidence. ${ }^{21}$

Torin Monahan has noted that the series casts a dubious eye on social efforts to ease economic suffering and injustice, reflected in the fact that the novels depict Nicolas Carpathia, the Antichrist incognito, as using such methods to gain international credibility and manufacture trust as he increasingly gathers earthly power to himself. Suspicion, not godliness, underlies a true Christian's response to efforts to engage in large measures to combat poverty, hunger and need. ${ }^{22}$

This indifference to human suffering and injustice as tangential to God's deeper agenda is consistent with premillennial dispensational views past and present. In 1947 American evangelical leader Carl Henry wrote The Uneasy Conscience of Modern Fundamentalism, in which he noted the near- total absence from conservative Protestant pulpits of any mention of the pressing social issues of the day, justified by an eschatology that assumes poverty and injustice are inevitable and that the church exists to save people out of the now and future mess. He warned against the "prophetic conference rather than Pentecostal challenge" and called for serious ecclesial engagement with issues of injustice rooted in biblical faith. ${ }^{23}$

Therefore, accepting the dispensational prophetic certainty of injustice makes efforts to combat poverty and assorted social ills beyond personal acts of kindness and band-aide occasional church charities seem like wasted effort. Hal Lindsey expressed the approach with brusque eloquence when, asked about the social passivity toward injustice in his views, replied, "God did not sent me to clean the fishbowl. He sent me to fish." While this sounds callous, it is perfectly consistent and even compassionate from the point of view that no social justice act can bear lasting fruit; only the salvation of the individual that readies them for the Rapture can have eternal consequence. $^{24}$

\footnotetext{
${ }^{21}$ Tim Lahaye and Jerry Jenkins, Left Behind, 2-3.

${ }^{22}$ Torin Monahan, "Marketing the Beast: Left Behind and the Apocalypse Industry," in Media Culture Society 30 (2008) 824.

${ }^{23}$ Carl F.H. Henry, The Uneasy Conscience of Modern Fundamentalism (Grand Rapids: Wm. B. Eerdmans, 1947), 45

${ }^{24}$ Paul Boyer, When Time Shall Be No More, 299.
} 
As Macaskill and others have noted, Revelation is not devoid of Christian social conscience, nor does it limit that conscience to unease over purely personal naughty acts. Economic strategies and policies that serve to repress or deny fair access to the larger community are identified as incompatible with God's will and under divine judgment. Extravagance purchased at the cost of marginalizing others is noted and denounced in the church of the Laodiceans (Revelation 3:15-20). ${ }^{25}$

While many fundamentalist churches have adopted that general understanding, significant segments within the evangelical Protestant community and tradition have retained and nurtured an active Christian social conscience. Timothy Smith, in his award-winning PhD research at Harvard, published as Revivalism and Social Reform, a massively researched work with no reference to premillennial dispensational views, documented the vigorous engagement of a variety of Christian evangelical traditions in the abolition of slavery, the empowerment of women, and the amelioration of working conditions for the poor in $19^{\text {th }}$ century America. Richard Stearns, President of the evangelical relief agency World Vision, calls attention to the need for consistent evangelical engagement in matters of poverty and justice as true faithfulness to the Christian prophetic tradition, thus avoiding what his book title reflects, The Hole in our Gospel. Without naming names, Stearns implicitly rejects any hermeneutic in which the poor are the ones who are "left behind." 26

\section{Political Impact}

In matters of political and international understanding, the Left Behind template has been the source of debate as to its impact on evangelical or fundamentalist voters and attitudes toward national policy issues. Paul Boyer traces the recurring influence of premillennial dispensationalism on churches and individuals that clearly has had an impact on the attitude of support for the modern state of Israel, the conviction that a last world war will begin in the Middle East, and that the policies of Russia, Iran, Egypt and Iraq in creating conflict are foretold in scripture and inevitable.

\footnotetext{
${ }^{25}$ See Grant Macaskill, “Critiquing Rome's Economy: Revelation and its Reception in the Apostolic Fathers, draft copy subsequently published in Engaging Economics: New Testament Scenarios and Early Christian Interpretation, edited by Bruce Longenecker and Kelly Liebengood (Grand Rapids: Eerdmans, 2009).

${ }^{26}$ Timothy Smith, Revivalism and Social Reform: American Protestantism on the Eve of the Civil War (New York: Harper Torchbooks, 1957). See also Richard Stearns, The Hole in our Gospel (Nashville: Thomas Nelson, 2009), 2223 offers comparisons from Revelation to contemporary poverty and justice.
} 
In the United States, politicians espousing views compatible with this world view have received strong support from such church groups. ${ }^{27}$

Amy Frykholm, writing specifically on the impact of the Left Behind series on political and international attitudes, echoes this theme. Concern over perceptions of a one-world government ruled by the Antichrist has created suspicion over the true evil purpose of collaborative international organizations such as the European Union and the United Nations. Modern technological and scientific advances likewise are seen as mixed blessings, not so much based on serious ethical analysis of implications as signs that the end is near, when "people will be coming and going and knowledge will be increased" (Daniel 12:4). ${ }^{28}$

As previously noted, the historic Reformed tradition has cast a jaded eye on the Left Behind ecclesiology and the Darby-Scofield suspicion of the existing organized Christian faith. The Wesleyan Arminian evangelical tradition likewise has ignored the premillennial dispensational approach to the apostate nature of churches, as part of the larger shrugging-off of this template for understanding eschatology. A number of Denver Seminary faculty members from the Conservative Baptist tradition and other evangelical scholars contributed to the recent anthology of essays affirming historic Premillennialism as "an alternative to the Left Behind eschatology." Prudence is required before casually assuming that the large sales of books imply profound and specific implications for churches with members who have bought the books. ${ }^{29}$

Patrick Egan has noted the emphasis on separation from the world and from apostate churches in the Left Behind series, in which both the Tribulation Force of the post-Rapture faithful and the Rapture itself reflect a borderline-Manichean notion of good and evil and the importance of the good totally removing itself from the evil. Although suffering from occasional fuzziness of language in overlapping evangelicalism and fundamentalism, Egan rightly sees the separatist tendencies as notions birthed by the separatist fundamentalist origins of the authors. This is completely consistent with the self-definition of Christian fundamentalism offered in the mainstay

\footnotetext{
${ }^{27}$ Paul Boyer, When Times Shall Be No More, 298-9.

28 Amy Frykholm, Rapture Culture, 118-121. See also Patrick Egan, "The Cultural Background of the Modern Fictionalization of Revelation (Part 2)," (lecture, Revelation and the Contemporary World, University of St Andrews, 2013).

${ }^{29}$ Craig Blomberg and Sung Wook Chung, A Case for Historic Premillennialism: An Alternative to 'Left Behind' Eschatology (Grand Rapids: Baker Books, 2010). While Dispensationalism was unknown to the church prior to J.N. Darby in the 19th century, Premillennialism in some form was known to early leaders such as Papias, Irenaeus, and Justyn Martyr.
} 
history of that movement from the former chair of the History Department at Bob Jones University, where the separatist character of the movement is articulated and embraced. ${ }^{30}$

The Left Behind series, popular as it has been, represents an approach to interpreting the book of Revelation outside the historic and current Christian mainstream, including much of the Western evangelical Protestant movement. The selective literalism and the inherent misreading of the nature of apocalyptic literature in general render the Lahaye approach problematic at best. Orthodox mainstay Gresham Machen's labeling of the approach as “a false method of interpreting scripture" provides the decisive judgment on the premillennial dispensational perspective for many evangelicals as well as more liberal interpreters. ${ }^{31}$

The impact of this series on the Western evangelical Protestant subculture likewise is problematic. Strong evangelical engagement in social justice, rational political discourse, collaborative ministries and legitimate science undercut fears that the more reactionary implications of a Left Behind ideology are swaying large numbers of American and British evangelicals in extreme directions. Major polls and studies likewise offer clarity of a life perspective more expansive among evangelicals than the world of Left Behind theology would suggest. As most readers of the Dan Brown Da Vinci Code novels have not drawn decisive conclusions about the Roman Catholic church from those pieces of fiction, so the overwhelming number of modern evangelical Protestants wisely are looking elsewhere than Left Behind in seeking deeper understanding and more faithful practice of the Christian faith.

\footnotetext{
${ }^{30}$ Egan, "The Cultural Background.” See George Dollar, A History of Fundamentalism in America (Greenville: South Carolina, Bob Jones University Press, 1973): 3-5.

${ }^{31}$ D.G. Hart, Defending the Faith, 64.
} 


\section{Bibliography}

Barker, Glenn. “1, 2 and 3 John.” In The Expositor's Bible Commentary, Vol 12, ed. Frank Gaebelein. Grand Rapids: Zondervan, 1981.

Bauckham, Richard. The Theology of the Book of Revelation. Cambridge: Cambridge University Press, 1993.

Beale, G.K. The Book of Revelation. Grand Rapids: Wm. B. Eerdmans, 1999.

Blomberg, Craig and Sung Wook Chung. A Case for Historic Premillennialism: An Alternative To "Left Behind" Eschatology. Grand Rapids: Baker Books, 2010.

Boyer, Paul. When Time Shall Be No More: Prophecy Belief in Modern American Culture. Cambridge: Harvard University Press, 1992.

Clouse, Robert. The Meaning of the Millennium: Four Views. Downers Grove: Intervarsity Press, 1977.

Collins, Francis. The Language of God: A Scientist Presents Evidence for Belief. New York: Simon \& Schuster, 2006.

Dollar, George. A History of Fundamentalism in America. Greenville, SC: Bob Jones University Press, 1973.

Egan, Patrick. "The Cultural Background of the Modern Fictionalization of Revelation (Part 2)." Class Lecture, Revelation and the Contemporary World, University of St. Andrews, 2013.

Frykholm, Amy. Rapture Culture: 'Left Behind' in Evangelical America. New York: Oxford University Press, 2004.

Hart, D.G. Defending the Faith: J. Gresham Machen and the Crisis of Conservative Protestantism in Modern America. Phillipsburg, NJ: P\&R Publishers, 1994.

Henry, Carl F.H. The Uneasy Conscience of Modern Fundamentalism. Grand Rapids: Wm. B. Eerdmans, 1947.

Hoekema, Anthony. “Amillennialism." In The Meaning of the Millennium: Four Views, Robert Clouse, ed. Downers Grove: Intervarsity Press, 1977.

Lahaye, Tim and Jerry Jenkins. Kingdom Come. Carol Stream, Il: Tyndale House, 2007.

Left Behind. Carol Stream, Il: Tyndale House, 1995.

Macaskill, Grant. “Critiquing Rome's Economy: Revelation and its Reception in the Apostolic Fathers.” In Engaging Economics: New Testament Scenarios and Early Christian, edited by Bruce Longenecker and Kelly Liebengood. Grand Rapids: Wm. B. Eerdmans, 2009.

Monahan, Torin. "Marketing the Beast: Left Behind and the Apocalypse Industry." Media Culture Society 30 (2008): 813-830.

Mounce, Robert. The Book of Revelation. Grand Rapids: Wm. B. Eerdmans, 1977.

Numbers, Ronald. The Creationists: The Evolution of Scientific Creationism. Berkeley: University of California Press, 1992. 
Putnam, Robert and David Campbell. American Grace: How Religion Divides and Unites Us. New York: Simon \& Schuster, 2010.

Reasoner, Vic. "The Hope of a Christian World: Wesleyan Eschatology and Cultural Transformation." The Arminian Magazine, Vol. 25, Issue 1 (Spring, 2007): 1-4.

Smith, Timothy. Revivalism and Social Reform: American Protestantism on the Eve of the Civil War. New York: Harper Torchbooks, 1957. 